University of Warwick institutional repository

This paper is made available online in accordance with

publisher policies. Please scroll down to view the document

itself. Please refer to the repository record for this item and our

policy information available from the repository home page for further information.

To see the final version of this paper please visit the publisher's website. Access to the published version may require a subscription.

Author(s): Chris King-Chi Chan and Pun Ngai

Article Title: The Making of a New Working Class? A Study of Collective Actions of Migrant Workers in South China

Year of publication: 2009

Link to published version :

http://dx.doi.org/10.1017/S0305741009000319

Publisher statement: none 


\title{
The Making of a New Working Class? A Study of Collective Actions of Migrant Workers in South China*
}

\author{
Chris King-Chi Chan and Pun Ngai
}

\begin{abstract}
In this study, we argue that the specific process of the proletarianization of Chinese migrant workers contributes to the recent rise of labour protests. Most of the collective actions involve workers' conflict with management at the point of production, while simultaneously entailing labour organizing in dormitories and communities. The type of living space, including workers' dormitories and migrant communities, facilitates collective actions organized not only on bases of locality, ethnicity, gender and peer alliance in a single workplace, but also on attempts to nurture workers' solidarity in a broader sense of a labour oppositional force moving beyond exclusive networks and ties, sometimes even involving cross-factory strike tactics. These collective actions are mostly interest-based, accompanied by a strong anti-foreign capital sentiment and a discourse of workers' rights. By providing detailed cases of workers' strikes in 2004 and 2007, we suggest that the making of a new working class is increasingly conscious of and participating in interest-based or class-oriented labour protests.
\end{abstract}

As a result of 30 years of reform, today China has become a "world factory" giving a sense of pride to a nation which was once conceived as a developing country and now poses a challenge to the global economy. A factor that has been little considered is the formation of a new working class whose life struggle has been continuously part of the process of making China a "world factory." The process of proletarianization in reform-era China has contributed to a new working class which is now increasingly conscious of and participating in various forms of collective action. Spontaneous strikes by migrant workers in South China have been multiplying since the mid-1990s. ${ }^{1}$ Even though it is difficult

* The authors are grateful to Simon Clarks, Chris Smith, Kim Koss, Peter Evans, Ruth Milkman and Greg Chin for providing valuable comments on earlier versions of this article. We would also like to acknowledge the funding support of Warwick Postgraduate Research Fellowship, RGC's project on "Making a new working class: a study of collective actions in a dormitory labor regime of South China" (2007-09), and the large-scale research project on "The formation of working class community in China" supported by APSS, Hong Kong Polytechnic University.

1 See Anita Chan, China Workers Under Assault: Exploitation and Abuse in a Globalizing Economy (New York: M.E. Sharpe, 2001); Ching Kwan Lee, "Three patterns of working-class transitions in China," in Françoise Mengin and Jean-Louis Rocca (eds.), Politics in China: Moving Frontiers 
to estimate the true number, official statistics reveal that between 1993 and 2005 the number of mass incidents rose dramatically from about 10,000 to $87,000-$ a 20 per cent annual increase on average - and 75 per cent of these protests were launched by workers and peasants. ${ }^{2}$ According to national statistics, the number of labour disputes at arbitration soared from 135,000 in 2000 to 314,000 in 2005 , an average increase of 18.4 per cent per year. In 2003, the number of employees involved in labour arbitration reached 801,042.

Through looking into the collective actions of migrant workers in the Pearl River Delta, this article sets out to make sense of the realities and complexities of the making of a new class. It argues that most of the recent collective actions involve workers' conflict with management at the point of production, while simultaneously entailing labour organizing in workers' dormitories and communities. These collective actions are mostly interest-based, accompanied by a strong anti-foreign capital sentiment and a discourse of workers' rights. They are not only organized on bases of locality, ethnicity, gender and peer alliance in a single workplace, but also attempt to nurture workers' solidarity in the broader sense of a labour oppositional force moving beyond exclusive networks and strong ties. Cross-factory strike tactics are sometimes used to invite workers from the same industrial region to participate in marches, street protests or highway blockages.

This study looks at the recent development of collective actions using two cases of labour strikes by migrant workers in 2004 and 2007. By analysing the detailed processes of workers' protests, we suggest that the making of a new working class is increasingly conscious of and participating in interest-based or class-oriented labour protests.

\section{Labour Collective Actions}

Studies of collective actions of laid-off state enterprise workers in north and central China ${ }^{3}$ suggest that "workers' identity," "class-consciousness" and "labour

footnote continued

(New York: Palgrave Macmillan, 2002), pp. 62-91; Ching Kwan Lee, Against the Law: Labor Protests in China's Rustbelt and Sunbelt (Berkeley: University of California Press, 2007); and Isabelle Thireau and Hua Linshan, "The moral universe of aggrieved Chinese workers: workers' appeals to arbitration committees and letters and visits offices," The China Journal, No. 50 (2003), pp. 83-103.

2 Pak Nang Leung, "The new working class in struggle: a case study of collective action in gemstone industry," MPhil thesis, The Hong Kong University of Science and Technology, 2007, p. 3.

3 See Marc J. Blecher, "Hegemony and workers' politics in China," The China Quarterly, No. 170 (2002), pp. 283-303; Yongshun Cai, State and Laid-Off Workers in Reform China: The Silence and Collective Action of the Retrenched (London: Routledge, 2006); Feng Chen "Industrial restructuring and workers' resistance in China," Modern China, Vol. 29, No. 2 (2003), pp. 237-62; Feng Chen, "Privatization and its discontents in Chinese factories," The China Quarterly, No. 185 (2006), pp. 42-60; Ching Kwan Lee, "Pathways of labor insurgency," in E. J. Perry and M. Selden (eds.), Chinese Society: Change, Conflict and Resistance (London: Routledge, 2000), pp. 41-46; Ching Kwan Lee, "From the specter of Mao to the spirit of the law: labor insurgency in China," Theory and Society, No. 31 (2002), pp. 189-228; Lee, 
struggles" are highly contested notions. According to E. P. Thompson, "class happens when some men, as a result of common experiences (inherited or shared), feel and articulate the identity of their interests as between themselves, and as against other men whose interests are different from (and opposed to) theirs." "In China's new industrial zones the language of class is subsumed and collective actions still lack a formal political agenda working against the state, but this does not mean that "interest-based" or "class-oriented" collective actions cannot germinate in this rapidly shifting society. ${ }^{5}$

This study is based on our longitudinal fieldwork in the industrial town of Shenzhen between 2003 and 2007. During this period we conducted intensive research into migrant workers' working and social life in the town by participant observation, interviews and documentary research in dormitories, migrant communities and workers' centres. This article compares two cases of strikes and protests. Factory A is Taiwanese-owned and had a strike in 2004, while factory B, owned by a German company, experienced a strike in 2007.6 Despite the differences in capital composition and the time of the strikes there are many similarities between these two factories. In the same electronics sector, both were set up in Shenzhen in the early 1990s and expanded rapidly into giant factories, with subsidiary plants in other parts of the Delta. They are situated close together, separated only by a highway, in one of the most strike-prone areas in the region. The wage levels in the two factories before the strikes were among the best in the town. However, both strikes encouraged a series of strikes in other factories causing substantial effects and wage increases within the town. We selected these two factories because they are in the frontier of dynamic changes in labour relations in the Delta. The three-year gap from 2004 to 2007 also made it possible to compare the changing patterns of labour conflict and predict future potential.

Data for factory A were collected in late 2005 and early 2006. We spent around one year interviewing workers, observing their working and social life and visiting their workplaces, dormitories and private rented homes. We interacted with more than 100 workers, with 20 deeper interviews or follow-ups. Our study of factory B also began in 2005 as part of an electronics industry labour conditions research project, continuing later under a dormitory research project.

footnote continued

Against the Law; and Mary Elizabeth Gallagher, Contagious Capitalism: Globalization and the Politics of Labor in China. (New Jersey: Princeton University Press, 2005).

4 E. P. Thompson, The Making of the English Working Class (Harmondsworth: Penguin, 1963), p. 9.

5 I. Katznelzon, "Working-class formation: constructing cases and comparison," in I. Katzneson and A. R. Zolberg (eds.), Working-class Formation: 19th-century Patterns in Western Europe and the United States (Princeton: Princeton University Press, 1986), pp. 14-20.

6 The factory A data were based on Chris Chan's community-based fieldwork from 2005 to 2006, which was the major part of his doctoral study on industrial conflicts in South China. Data for factory B were collected alongside a dormitory research project led by Pun Ngai from 2003 and joined by Chris Chan at a later stage. Our approach was to study the unique labour regime in China's global factories, starting from the reproduction sphere and extending into the production sphere. We would like to thank our friends and colleagues who shared with us important information which formulated this article. 
Our fieldwork in August 2007 coincided with the occurrence of the strike in factory B. We used the contacts we had built up and maintained from 2005 to observe the development of the strike and conduct interviews with 50 workers. Our research into these two factories also extended into their subsidiary plants in other towns and cities. We visited a subsidiary of factory A in the city of Huizhou 惠州 in March 2006 and a subsidiary of factory B in August 2007 in a town close to Shenzhen's international airport.

The first question we considered was: when, where and how will workers develop collective actions? Drawing on rich ethnographic findings, we argue that at critical junctures - often when discontent and grievances are shared migrant workers will tend to take action collectively, transgressing the barriers of locality and ethnicity to generate an interest-based or class-based industrial struggle.

This led us to the next questions. When the workers' discontent and grievances are shared, what makes them likely to engage in collective actions? What resources are available for the aggrieved workers to use in resistance and protest? Scholarship on Chinese labour suggests that Maoist discourse, new-found legal mechanisms and localistic networks are useful potential resources. The Maoist legacy and the government's legal reforms have opened up discursive space and institutional channels for workers to frame their collective interests as rights, ${ }^{7}$ although these channels will not stop them transforming into interest- or classbased struggles at a later stage. Without effective assistance from the Chinese trade union system, the workers have no choice but to rely on their own preexisting localistic networks to build cultures of solidarity, ${ }^{8}$ but once the workers' solidarity is built, they can articulate their aggregate interests along the line of class.

We further explore the creative forms of workers' resources and mass mobilization at their workplaces and living spaces, including consideration of the internal contradictions which can develop. All these resources for action and collective mobilization are double-edged swords. Labour laws set the limits of compensation claims and outcomes. Localism suggests boundary-drawing and social exclusions between sub-groups of workers. Dormitories are also strategic sites of managerial control extended beyond the shop floor, enabling managers to tighten control over workers in their living space. As a response, privileged workers

7 Feng Chen, "Industrial restructuring and workers' resistance"; Neil J. Diamant, Stanley B. Lubman and Kevin J. O'Brien (eds.), Engaging the Law in China: State, Society, and Possibilities for Justice (Stanford: Stanford University Press, 2005); Lee, "From the specter of Mao to the spirit of the law"; Lee, Against the Law; and Thireau and Hua, "The moral universe of aggrieved Chinese workers."

8 For a thorough understanding of the concept of "cultures of solidarity," see Rick Fantasia, Cultures of Solidarity: Consciousness, Action, and Contemporary American Workers (Berkeley: University of California Press, 1988). For detailed discussions on localistic networks in Chinese factories, see Elisabeth Perry, Shanghai on Strike: The Politics of Chinese Labor (Stanford: Stanford University Press, 1993); Gail Hershatter, The Workers of Tianjin, 1900-1949 (Stanford: Stanford University Press, 1986); Emily Honig, Sisters and Strangers: Women in the Shanghai Cotton Mills, 1919-1949 (Stanford: Stanford University Press, 1986); and Ching Kwan Lee, Gender and the South China Miracle: Two Worlds of Factory Women (Berkley, CA: University of California Press, 1998). 
escape this rigid control by moving out to urban migrant communities where they can more easily engage in collective action.

\section{Production, Reproduction and Proletarianization of Migrant Workers}

The specific process of proletarianization of Chinese migrant workers is shaped by the spatial separation of production and reproduction of labour by China's household registration system and rural-urban chasm, and a spatial re-combination of these two dimensions by a dormitory labour regime. ${ }^{9}$ Dormitory use for labour has a long history in China. ${ }^{10}$ What is interesting here is not the recurrence of an old form of labour use in global production, but the reconfiguration of hybrid forms of work-residence for the daily reproduction of labour and the embodiment of labour control and resistance in contemporary China. Since the role of the state is almost missing in providing the support of collective consumption to the new working class in the industrial cities and towns, the provision of dormitories to accommodate millions of migrant workers becomes a necessity for enterprises that produce for the global market, and hence take up the role of the daily reproduction of labour power. The specificity of the Chinese dormitory labour system is the widespread use of dormitory labour in all newly industrialized zones in China, irrespective of capital, sector, industry and factory. ${ }^{11}$

Factory dormitories were first introduced into China in the early 20th century on a limited scale. In a study of cotton and silk workers in Tianjin from 1900 to the 1940s, Gail Hershatter notes that dorms were introduced to lower labour costs through feminization and use of rural workers in foreign-owned companies. ${ }^{12}$ A similar study of female cotton workers in Shanghai in the 1930s by Emily Honig also notes that contractors hired thugs to guard the dormitories and accompany women workers. ${ }^{13}$ One characteristic of China's foreign-invested plants since 1978 is the housing of migrant workers in dormitories attached to or close to a factory's enclosed compound. The managers of these companies appear to have exceptional control over the workforce. Within a dormitory labour regime, working days are extended to suit production needs, resulting in a flexible utilization and prolonging of labour time and a greater breadth of control into the working and non-working day of the workers. In the dormitories, the workers already joined to one another along gender, locality, kinship and ethnic lines are linked to widespread networks inside and outside the workplace setting. To escape the disciplinary control within the factory-provided dormitories, some

9 See the detail in Pun Ngai and Chris Smith, "Putting transnational labour process in its place: the dormitory labour regime in post-socialist China," Work, Employment and Society, Vol. 21, No. 1 (2007), pp. $27-45$.

10 See Chris Smith, "Living at work: management control and the dormitory labour system in China," Asia Pacific Journal of Management, Vol. 20, No. 3 (2003), pp. 333-58.

11 Pun and Smith, "Putting transnational labour process in its place."

12 Hershatter, The Workers of Tianjin, pp. 165-66.

13 Honig, Sisters and Strangers, p. 106. 
higher-paid workers rent temporary settlements in the communities near their factories. These communities continue to nourish gender, locality and peer networks in connection with the dormitories. It has been widely noted that kin and ethnic networks facilitate migration flows, job searches and the circulation of work information, and that they strengthen workers' capacity to cope with factory life and the hardships of the city. ${ }^{14}$ With the development of a new generation of migrant workers who were born after the 1980s, we also observe that exclusive locality networks and gender lines can be transgressed to create a broader sense of "workers' networks." It is clear that workers' cultivation of a collective spirit reveals the powerful influence of kinship, ethnicity and gender, but at the same time it showed an interest-based orientation, especially in times of struggle. ${ }^{15}$

Workers who find themselves in the midst of a crisis or a strike easily transform these "soft" supports - the kinship networks, ethnic enclaves, spirit of sisterhood and personal relationships - into "hard" resources for industrial struggle. In a number of cases, we recorded the presence of petition letters that, circulating from dorm to dorm, collected many signatures in a single night. The relative ease with which workers could use the dorm setting to organize their common cause against management derives, in large measure, from the limited space that dormitories offer opponents of collective action. On strike, workers efficiently and spontaneously organize themselves, receiving little or no formal help from trade unions or labour organizations. The compression of time in the dormitory labour regime that is necessary for production also works in favour of collective worker organization by accelerating consensus-building and strategy development. On the other hand, a significant number of migrants, especially skilled and supervisory workers, rented private rooms in the local community known as the "peasant-workers' village" (mingong cun 民工村). ${ }^{16}$ This rising community also provided the potential for a new form of workers' militancy despite internal divisions and conflicts.

To see whether the living space facilitates workers' mobilization, we provide a detailed analysis of two strikes, one in 2004 and the other in 2007, in the same industrial city in the Pearl River Delta. In both cases, most of the ordinary workers lived in the factory-provided dormitories, while the skilled and supervisory staff tended to live in private rented rooms and shared flats in the local village. ${ }^{17}$ In factory A more than 30 per cent of the workers had left the dormitories

14 See Lee, Gender and the South China Miracle; Pun Ngai, Making in China: Women Factory Workers in a Global Workplace (Durham: Duke University Press, 2005).

15 Perry, Shanghai on Strike.

16 It was reported that $48.7 \%$ of the migrant population in Shen Zhen live in privately let "peasant" residences, see Guo Wu Yuan Yan Jiu Shi Ke Ti Zu (State Council Research Institute Project Team), Zhongguo nong mingong diaoyan baogao (The Report on Chinese Peasant Workers) (Beijing: Zhongguo yanshi chubanshe, 2006).

17 For a portrait of migrant workers' urban temporary community, see Zhang Li, Strangers in the City: Reconfigurations of Space, Power, and Social Networks within China's Floating Population (Stanford: Stanford University Press, 2001). 
and rented private rooms in the village where, in 2006, their rent ranged from 150 to 250 yuan per month. The village had many corner shops, most run by workers or ex-workers. Besides selling food, wine and cigarettes the shops rented instruments for playing Mahjong (majiang 麻将), a traditional Chinese game with four players, and hence provided one of the major social spaces for migrant workers. In factory B, until 2006, the factory gave a 50 yuan subsidy to production workers living outside. Skilled workers, supervisors and managers received higher subsidies: line supervisors, for example, received 200 yuan. As a result, most of the skilled workers and supervisors lived outside the factory. Workers' living space has a significant impact on the strategies and consequences of workers' struggle in both factories.

\section{Case 1: Taiwanese Factory Strike in 2004}

Factory A, which produces small household appliances, was set up in 1992 with between 20 and 30 workers. By 2004 it had expanded to a two-factory complex with a workforce of 9,000. The factory operated two shifts and workers had to work 12 hours per day for seven days a week with two meal breaks of half an hour each. The local legally prescribed minimum wage in 2004 was 480 yuan per month for a 40-hour working week with weekday overtime pay at 1.5 times and weekend overtime at twice the normal rate. But workers were paid below the standard. A production worker's basic salary was 450 yuan covering eight hours work from Monday to Saturday. Overtime work above the eight hours and on Sunday was paid at an hourly rate of 2.4 yuan. Production workers earned from 700 to 1,300 yuan, dependent on hours of overtime. On top of the basic salary and overtime pay, which were universal, there were extra subsidies for some departments and posts. A line supervisor had a 400-500 yuan subsidy and a workshop supervisor 700-800 yuan, while their overtime pay was the same as production workers. The factory provided dormitories for all workers, and deducted 50 yuan per month from their salaries for rent and bills.

In April 2004, the factory began a new policy which triggered off the strike. During the half-hour lunch break from 11.00 to 11.30 a.m., workers were requested to punch their attendance cards twice, in and out. As a result a long queue appeared behind the punching machine. Discontent soon began and spread among the workers.

On 10 April, the strike began in one of the production departments on the fifth floor of the factory building. The next day it spread to the whole factory. As well as challenging the punching issue, workers requested that their salary be increased from 450 to 480 yuan and overtime pay from 2.4 to 3.5 yuan per hour. A notice calling for a strike was stuck up in every department and between 100 and 200 workers from the initiating department walked out to block a national highway. However, some were stopped and persuaded back by their managers and the rest were driven off by the police. Seven were arrested and detained separately at the police station. 


\section{Labour mobilization in workplace and living space}

A group of young male workers from the initiating department then went through the factory turning off or breaking the general electricity switches, and were supported by the older and experienced workers. Nearly all the production line workers, both male and female, stopped work and walked out. Thousands stood outside the factory to stage a strike. The town officials and police arrived and, at noon, the factory requested the workers to elect their representatives. There was no formal election but ten male workers volunteered, five of whom were veteran workers in the initiating department. Negotiations were held in the afternoon and workers gathered outside the meeting room to wait for the result. However, at the end of the meeting, the ten representatives were sent out of the factory by van and disappeared.

In the evening, some of the workers were annoyed enough to rush into the administrative office, break the computers and drive the Taiwanese general manager and local factory director off to the entrance of the factory, where thousands of workers were gathered. The furious workers attempted to beat the Taiwanese manager. Two security guards then dragged the manager back into the factory. A witness described the scene ${ }^{18}$ :

There were 2,000 to 3,000 workers at the scene of the factory entrance who requested the Taiwanese lao (佬, guy) [the general manager] to come out and explain. The Taiwanese lao finally came out at 9.00 p.m. As soon as he appeared, those standing outside the entrance pushed inwards, while those inside crowded out, all were screaming and shouting. Someone shouted, "kill him! kill him!" Four or five security guards promptly dragged the Taiwanese lao into the factory and closed the gate. By then, most of the workers had come out of the factory compound. Roaring and shouting, furious workers managed to climb over the gate. Others flung cigarette butts, water bottles and rubbish on to the body of the Taiwanese lao. Half a bottle of water was just thrown down on the head of the Taiwanese lao. Restraining his temper, the Taiwanese said, "Don't throw this stuff, don't throw stuff. Wages can be raised."

One of the workers cursed, "You Taiwanese guys do not treat us [mainland Chinese] as human."

The Taiwanese responded, "I treat you equally. We are the same."

Workers shouted, "Raise the wage according to the law!"

He said, "I agreed. I promised to raise your salary ..."

Workers continued to debate with him. Around 100 workers stayed on overnight to block the factory and stop the factory sending products and goods off.

It is clear that the workers were united and formulated a strong oppositional force against the management. Even though the language of class was never used in their actions, workers' awareness of their oppositional position against capital in the production realm was acutely apparent, sometimes even involving moments of violence. Their swift mobilization power was facilitated by the intense linking between production realm and living space. A framework of legalism was also transgressed when we observed the strike on its third, fourth and fifth days - when the workers moved beyond claiming a legal standard wage to 
demanding the release of their representatives and staging a petition to the city government. ${ }^{19}$

On the morning of the third day, the factory posted a notice stating that the wage would rise to the minimum legal standard. Workers, however, installed a big board card behind the attendance punching machine, informing workers to sign a petition to the city government for the return of their representatives. Two to three thousand workers then walked from the factory to the national highway. They were stopped after ten minutes on the highway by hundreds of police, military police and government-employed security guards. The labour bureau officials persuaded them to return to the factory, and promised that they would come to help negotiation: "as long as you go back, we can talk about any conditions on the table."

When the workers arrived back at the factory the Taiwanese managers had all escaped to a neighbouring Taiwanese factory, and the workers found they had been deceived. Discontent became widespread all over the factory. In the evening, a bigger mobilization was formed throughout the shop floors, dormitories and village with support from skilled workers and supervisory staff who acted as organizers. Some workers spontaneously prepared their own slogans. In many corners of the village, workers discussed and made preparations for the big confrontation.

In the early morning of the fourth day, a message was widely spread among ordinary workers. "In dormitories, private buildings and even street corners, there were people asking others to 'go to the city government'," a worker recalled. Two big banners were hung proclaiming slogans of "Return our ten workers' representatives" and "Factory A violates the labour law, doesn't raise wages!" Here can be seen the essential role of living space in labour organizing.

\section{Marching to the city government}

At 8.00 a.m. between 4,000 and 5,000 workers left the industrial district to march towards the highway. The protest was better organized, planned and co-ordinated than the one the previous day. This time the police were well prepared to block the demonstrators at the highway entrance, but to avoid a confrontation workers adopted an alternative strategy. As soon as the mass arrived at the junction, a leader announced over an amplifier: "Listen, we don't walk into the main road." Then workers began to flood on to the pavement. Hundreds of policemen and security guards still tried to stop them and they were surrounded by police, local militia and security guards from the city government. But the workers put up strong resistance by throwing bricks, stones and grass.

Beside the two high-rising big banners, there were at least three amplifiers, several cameras and fund-raising boxes. On the boxes was written "for our 
common interests, please put in your money," and they were soon full of money. The cameras were only used to take pictures when workers were beaten by policemen. Banners were held by younger workers, while skilled workers and supervisors were available to give directions at critical moments. Not long after the workers arrived at the edge of the highway, policemen shouted at those holding the banners: "Put it down! Put it down!" The young workers stepped back, and some older workers walking behind the banners helped take them away to avoid conflict with the police.

More and more workers from other factories in the same industrial district also gradually joined in the march along the way, to show support or just for fun. At 1.00 p.m., five hours after they had left the district, as many as 7,000 to 8,000 protestors were heading to the city government.

At this stage there was a confrontation. The police used a water hose to attempt to drive away the workers. As soon as the water shooting stopped, the workers lobbed stones and bricks at police. Workers saw a supervisor with an amplifier standing in the centre of them all, calling for others to push forward. Eight workers who had more physical conflict with the security guards were arrested, while 30 others were sent to hospital.

On the afternoon of the next (fifth) day, workers were told to attend a meeting in the factory canteen. District labour bureau officials, the police, the general manager and factory director all came to the meeting. The general manager reassured workers that both lunch and dinner times would be extended to one hour, and promised that the factory's policy would fully comply with the law. The curtain then fell on the protest, although without either the immediate release of the arrested workers or the return of the representatives to the factory.

Hundreds of supervisors and skilled workers were sent out to Huizhou to set up a new factory after the strike, and they spread the story of the battles in the Shenzhen workplace. Thereafter workers in both Shenzhen and Huizhou staged crossdepartment strikes from time to time. Strikes became a culture endemic in factory A.

\section{Case 2: German Factory Strike in 2007}

Factory B is a German capital enterprise which produces batteries, power cords and other components of mobile phones. It was set up in 1993 and expanded into two large plants in two industrial towns. Both employ about 8,000 workers, of which 80 per cent are women aged between 18 and 30. Like factory A, the wage level in factory $\mathrm{B}$ is better than in some of the other factories in the area. The minimum hourly wage rate is basically observed and social insurance is provided for all workers. The factory operates in two shifts. The day shift is from 7.00 a.m. to 6.30 p.m. with a one-hour lunch break, while the night shift is from 7.00 p.m. to 6.45 a.m. with a 45-minute mid-night break. Ordinary workers usually work six days per week and their monthly salary is between 1,000 and 1,400 yuan.

In this factory, production workers are called employees (yuangong员工), while others, including managers, supervisors, engineers, technicians and office 
clerks, are collectively called staff (zhiyuan 职员). Most of the workers, yuan gong, live in the factory-provided dormitories where between eight and twelve workers share a room and 30 yuan is deducted from wages as rent. The factory pays an accommodation subsidy of between 200 and 300 yuan per month to zhi yuan to rent private rooms outside the factory.

In July 2005, when the minimum wage rate in Shenzhen was raised to 580 yuan, the factory adjusted the salary accordingly. The minimum wage was further increased to 700 yuan in 2006 and workers again got an equivalent pay rise. After two years' consecutive pay rises, however, the factory steadily began to increase the work quotas of the production line and units. If workers cannot finish the quota set up unilaterally by the management for eleven daily working hours, they are asked to perform extra work the next day without payment. The practice creates conflict between more efficient experienced workers and the inexperienced, as well as between the front line supervisors - who announced the new quota and forced their subordinates to work faster - and the production workers. The most common reason for discontent in the factory has become "too exhausted" rather than low pay. Many workers quit within a year, but there was always a long queue for those applying to leave. For those who left without proper "permission," the factory confiscated their salary and prohibited them from re-entry to the factory within six months.

A special rationalization reform was also made in March 2007 to lower the wage cost of the zhiyuan by restricting their hours of permitted overtime. From July, the maximum overtime of zhiyuan was set at 72 hours per month. They would not get extra pay even if they had worked more than those hours. The impact for front line supervisors was that they had to take care of more lines when other supervisors were on leave. For technicians, a smaller number was on duty in each shop. As with factory A, repair technicians in the workshop are on stand-by. Some of them leave the factory after punching in their attendance cards and ask others to punch out for them. To stop this abuse, a new punching machine was installed in the main entrance of the factory in August 2007, especially for controlling zhiyuan.

The immediate cause of the strike was the city government's wage policy. As mentioned above, the city had significantly raised the minimum wage rate in July 2005 and 2006. Workers therefore expected a similar pay rise in July 2007, but the government decided not to raise the legal rate and maintained it at 700 yuan. A strike was immediately sparked off in August, the second day after the workers got their July pay slip.

\section{Collective action for a reasonable wage}

Workers got their pay slip on 16 August, a Thursday, and discovered that their salaries had not been raised. At the same time, technicians and supervisors found their income was severely reduced because of the overtime restriction. For example, one technician whose salary was always well over 2,000 yuan 
only received 1,400 yuan. On the Friday evening, when the managers who only work during the day had left the factory, a public letter was posted on the notice board of all the workshops.

The letter was issued in the name of all of the factory B workers and entitled "Voices from zhiyuan and yuangong." It began by pointing out that the management had attempted to lower their salaries from the end of 2006, and now their income had been reduced by 50 per cent compared with the same period last year, while the work quota and living costs had doubled. "We have reasonable demands," the letter stated ${ }^{20}$ :

1. To adjust our current wage standard. We all know the market wage standard now, and thus demand it should be adjusted to the following ways: yuangong, 1,500 yuan or more; second level zhiyuan, 2,000 yuan or more; third level zhiyuan, 2,500 yuan or more; fourth level zhiyuan, 3,000 yuan or more; the above does not include any subsidy.

2. To raise the accommodation and food subsidy for living outside.

3. To improve welfare conditions, provide reasonable allowance for high temperature, toxic, outdoor and occupational disease-prone posts and regular occupational disease and body checks.

4. To provide night shift subsidy and snack allowance for those working on the night shift.

5. The company should buy unemployment, maternity, medical care and all the other insurances requested by the Labour Law.

6. To solve the hygiene problem of drinking water.

7. To improve the reasonability of the overtime work.

8. The trade union should function appropriately and its core members should invite the grass roots (zhiyuangong 职员工) to participate in it.

The letter ended by stating that they requested the company to answer these demands in written form and they would not accept an oral reply from anybody, including the company CEO. News began to circulate among the workers that the technicians would start a strike soon.

\section{The leading role of male technicians in the strike}

On Monday morning, 20 August, soon after the production workers walked to their workshops at 7.45 a.m. as usual and prepared to begin work, the electricity was turned off. Supervisors told workers that there was a strike and asked them to leave the workshop. The newly installed card-punching machines for zhiyuan were broken. Thousands of workers stood around the main entrance of the factory.

From the very beginning of the strike, it was the male technicians in the engineering department who directed the collective action of the unorganized thousands of production workers. "A technician swung his work uniform (to attract attention) and several other technicians around him shouted: Go! Go! The workers then followed them in the direction they walked," a worker recalled. 
After more and more workers, mostly young women, joined in, the technicians led the crowd on to a crossroads in the industrial town. It was not a busy road and there were not many cars; several policemen just stood by the workers peacefully. "One policeman even told us that it was useless to stay there and we should go to the major national road," a worker said. Half an hour later, the workers walked to the national highway and occupied one half of the main road. At this point hundreds of forces, including patrol police, military police, transport police and local government security guards, came, followed by labour bureau officers, the town Party secretary-general and the factory managers. The local Party head, labour bureau representative and top manager addressed the crowd and asked them to go back to the factory for negotiation. Officers said that it was illegal to stand there and matters could be discussed in the factory, while the manager asked the workers to elect their representatives. Some of the workers stated that they were all representatives.

Some young workers standing in the front, most of them female, came into physical conflict with the police and several were arrested. Workers then retreated back the way they had come, shouting "release people!" Some of those arrested were released straight away while others were detained for around one week. Under the control of the police, the workers gathered around a petrol station and then dispersed peacefully. It can be seen that even though it was male technicians who controlled the leadership of the strike, female workers were the militants who had direct conflict with the police.

In the afternoon, the management called all the zhiyuan to a meeting. However, as the factory requested those attending to sign their names, almost all the technicians and some supervisors left. The meeting was therefore basically one of department heads and managers. There was no formal notice but news circulated that the meeting decided to increase the basic salary from 300 to 500 yuan for zhiyuan, dependent on position level, and by only 30 yuan for yuangong. The supervisory staff was mostly satisfied with this offer and went back to work from Monday night. But no single worker followed. Workers punched in their attendance cards as usual and then left the workshops. The workforce which had been united at all levels was now divided, but this internal division did not stop the strike.

\section{Female production workers' resistance in dormitories}

On Tuesday the strike continued. A notice was posted by the factory to announce the salary change and other decisions: a 50 yuan subsidy was granted to those living outside and night shift workers can have 1 yuan allowance per day. The managers and supervisors tried their best to persuade workers to go back to work. Some of them came to the dormitories. Despite its near-total domination of labourers' lives, the Chinese dormitory labour regime provides space for collective resistance. Now the production workers, mostly female, began to 
recognize that the supervisory staff had "betrayed" them. Some of them posted up slogans on the wall of the dormitory: "Strike to the last moment!" One of the workers who was forced to go back to work in the evening recalled her story. When she punched out her attendance card, her shop supervisor and department head stood by the machine.

They asked me to work, I refused. They said that I can just sign up my name. I thought that it was no problem if I only signed a name. I went into the workshop to sign my name. But afterwards, they did not allow me to leave and soon the gate closed. There were not enough workers to run a single line. Around ten workers just sat there for several hours with the lights on. After several hours, we were allowed to leave and we got pay for the full day of eleven hours. I felt very upset. I thought I had destroyed the solidarity of the workmates. So I did not go back to work on Wednesday. I just slept in bed unhappily. ${ }^{21}$

In the evening, while the managers had "successfully" pursued workers like this girl to go back to work, a well-typed pamphlet was circulated among the ordinary production workers. Some copies were thrown down from one of the dormitory buildings to the ground; others were distributed by workers outside the factory.

The pamphlet began by denouncing the zhiyuan and calling for unification of yuangong:

All brothers and sisters of yuangong,

We must be united. We don't need to care about those shameful zhiyuan and don't believe their lies. They have achieved their own goals. We, workers, don't want to waste the time of both sides either. We have very clear demands: if any of the following items cannot be accepted by the factory, we will definitely not walk half a step into the workshop. Our demands are:

1. Basic salary 810 yuan. Pay during leave should also not be lower than the basic salary.

2. No deduction of fees for living in dormitory; living outside should get appropriate subsidy.

3. Night shift should have a night snack allowance of 150 yuan paid on a one-month base.

4. Give those workers in toxic and detrimental conditions an appropriate subsidy and subsidize the outdoor staff according to the Labour Law (150 yuan).

5. The drinking water of all workers should reach the hygiene standard.

If you want to be a piece of meat on a cutting board or a shameful Hanjian (汉奸, Han traitor) then you can sell your body before we get our wage demand! We believe absolutely none of us is this kind of person. Fellow compatriots, it is our most fragile moment as those zhi yuan have achieved their aims, and forgotten the interests of us yuan gong. Brothers and sisters of yuangong of the whole factory, for the sake of our own interests, let's unite together. Chairman Mao said: our revolution has not been successful, struggle should continue, insist! Insist ... and insist.

From all yuangong

Beside the pamphlets, workers also put posters on the walls of the dormitories and sent mobile phone messages to ask others to carry on the strike. Encouraged by all these actions, most of the ordinary workers continued to strike on the third day. A significant moment came at noon on the fourth day. The company posted a new statement to announce that those who want to resign in three days could get back all their compensation and salaries, but others should go back to work. Workers who returned to work within three days would get an extra allowance: 50 yuan for the first day, 30 yuan for the second day and 10 yuan for the third 
day. Otherwise, they would be seen as "absent" and "quitting by themselves," implying that they would not be paid as usual.

This was good news for the many workers who were already in the long waiting list to leave the factory. The strike bolstered their determination and 3,000 queued up in the administrative department to apply to leave. However, the divisive strategy fatally shook the confidence of those workers who wanted to stay, in particular those with family financial responsibilities. When the supervisors phoned to ask workers to work, those who were under economic pressure to keep their job did not resist. At the same time, the factory provided distilled water in both dormitories and workshops. They promised to install air conditioning in workshops as well as a rest room with a television on each floor of the dormitories. They also promised a regular meeting with supervisors and encouraged more suggestions from the production workers. Despite these achievements, production workers' perception of being betrayed by the supervisory staff was very apparent. Most of them did not consider it a successful strike.

One of the significant features of this strike was that a strike also happened almost simultaneously at factory B's subsidiary factory in a different town. It resulted in the same improvement in wages, subsidy, welfare and conditions as at factory $\mathrm{B}$.

\section{Concluding Remarks}

In recent years, workers in foreign-owned enterprises in coastal China have more frequently resorted to strikes to express their grievances. ${ }^{22}$ In this study, we argue that recent labour protests are mostly interest-based, purposively induced to improve working conditions and oppose capital, which may or may not resort to legal means either at the beginning or at the end of the dispute. Without strong leadership or formal organization, most of the labour conflicts are triggered off squarely at the point of production, with the living areas as bedrock for labour mobilization.

In fact, the power relationship within the working and living areas cannot be understood by separating them from each other. Although the migrant workers' urban settlements are only temporary because of the constraint of the household registration system, the factory-provided dormitories function as a labour organizing space and resource. In factory A, the street corner as an effective organizing place was only made possible because of the power of the skilled and supervisory staff. In factory $\mathrm{B}$, from the second day of the strike, the dormitory blocks rose to be contested space for workers and management to manipulate. Women workers encouraged others to continue the strike while the managers came to try to persuade workers to return to work. Despite the transient nature

22 B. Taylor, K. Chang and Q. Li, Industrial Relations in China (Cheltenham: Edward Elgar, 2003); and Lee, Against the Law. 
of the settlements, workers' daily lives and collective struggle have the potential to form more inclusive labour actions.

Echoing the finding of Perry's study of the Shanghai strikes in the 1920s, both our cases showed that technicians, skilled workers and line supervisors acted underground in the organizing of strikes and protests. Labour historians have also suggested a similar prominent role of privileged groups in the early stages of workers' struggle in the West. ${ }^{23}$ Confirming the findings of Lee, the language of class was not used during the strikes. ${ }^{24}$ Instead, in both cases, terms based on place or nationality were used. However, it is also transparently clear that workers' strikes were highly permeated with a meaning of class interest or class division. The boss, the management and capital are still the first targets of labour protests.

Studies on protests by state-owned factory workers in the north suggest that the memory of Maoism was repeatedly used as a workers' weapon, ${ }^{25}$ but this was a sign of nostalgia rather than class consciousness. As the case of factory B showed, migrant workers also recalled the communist revolution and Chairman Mao to encourage further struggle at the "critical moment," although they misquoted the last words of Sun Yat-Sen as the words of Mao. Mao is still a cultural symbol of radical politics in the eyes of the new working class in China.

These political and cultural aspects of the collective actions might suggest a weak use of class consciousness by the migrant workers at this stage. Nevertheless, the two cases also provide hints of a potential labour movement in the future. First, although they were still factory based, both strikes had a significant knock-on effect on other factories in the same community and the same business group. According to our observations, the strike wave from 2004 to 2005 at least partially accounted for the dramatic rise of the legal minimum wage rate and the local state's better Labour Law implementation. Moreover, compared with the 2004 strike, it was a breakthrough that organizers in factory B were able to co-ordinate workers in two factories to stage a strike together in order to enhance their bargaining power. Second, the strikes also provided experience to improve struggle strategy. The strike in factory A in 2004 was more militant and violent than that in factory B in 2007. Factory B was better organized and workers' demands were articulated more clearly in written form.

Third, the workers' strike waves created a dilemma for the local state. Lee pointed out that migrant workers' struggle, individual or collective, always had a legal basis. ${ }^{26}$ Our cases show that workers' demands had gone beyond that. The immediate response of the local government to the strike in 2004 was to pressure the factory management to abide by the law and increase the legal

23 Thompson, The Making of the English Working Class; D. Nelson, Managers and Workers: Origins of the New Factory System in the United States 1880-1920 (Wisconsin: The University of Wisconsin Press, 1975); Katzneson, "Working-class formation," pp. 3-41; and L.R. Berlanstein, The Industrial Revolution and Work in 19th-Century Europe (London and New York: Routledge, 1992).

24 Lee, Against the Law.

25 Ibid. and Feng Chen, "Industrial restructuring and workers' resistance."

26 Lee, Against the Law. 
minimum wage rate. Such wage adjustment has the effect of satisfying and pacifying workers. But continual rise of the legal wage would lower the competitiveness of the city against other regions or countries. In 2007, when the legal minimum wage could not satisfy workers, workers' struggle was radicalized to demand a "reasonable" wage rate.

Fourth, despite their passive role in the strike, ordinary production workers were empowered by it. They well knew their own interests and were enthusiastic to take part in the strike. In factory A, even workers from other factories joined in the demonstration to show support or as a way to express their opposition to the "bosses" in general. In factory B, a woman worker who "pretended" to work on the second day felt guilty and did not go back to work on the third day.

Inspired by Thompson, we view the formation of a "class-for-itself" as a historical and long-drawn-out process that involves innumerable day-to-day struggles in a specific cultural context. ${ }^{27}$ The collective actions we studied were attempts to nurture workers' solidarity in a broader sense of a labour oppositional force moving beyond locality, gender and peer networks, and even involved cross-factory strike tactics. The workers' dormitory and urban communities, no matter how temporary, provide the potential to facilitate labour mobilization and collective consciousness building. Our research makes it clear that workers in the export-processing zones of China are able to unite along class line in times of crisis, sometimes even with strong anti-foreign capital sentiment and violence. 